NBER WORKING PAPER SERIES

SAVING AND INVESTMENT IN AN

OPEN ECONOMY WITH NON-TRADED GOODS

Char les Enge 1

Kenneth Kletzer

Working Paper No. 2141

NATIONAL BUREAU OF ECONOMIC RESEARCH

1050 Massachusetts Avenue

Cambridge, MA 02138

February 1987

I would like to thank Jonathan Eaton for extrememly useful comments. The research reported here is part of the NBER's research program in International Studies. Any opinions expressed are those of the authors and not those of the National Bureau of Economic Research. 
NBER Working Paper \#2141

February 1987

\section{Saving and Investment in an Open Economy with Non-Traded Goods}

\section{$\underline{\text { ABSTRACT }}$}

We examine a model of a small open economy in which there is free international mobility of financial capital, investment in capital goods and a non-traded good. Such an environment is rich enough to explain several phenomena that are inexpicable in more barren models. We suggest an explanation of why saving and investment may be correlated even with no restrictions on trade in assets. We explain why a high saving country may nonetheless borrow from abroad to finace investment. We also provide an optimizing model of stages in the balance of payments.

Charles Engel

NBER

1050 Massachusetts Ave.

Cambridge, MA 02138
Kenneth Kletzer

Economic Growth Center

Box 1987

Yale Station

New Haven, CT 06520 
1. Introduction

Two important but often neglected features of almost all open economies are that they trade investment goods and there are some goods which are non-traded. We explore such an economy in a dynamic model with perfect international mobility of financial capital. In this context we can explain several phenomena that are inexplicable in more barren models.

Consider the following questions:

-. In a world where financial assets are freely traded, are saving and investment decisions independent?

- If a country postpones consumption in order to reach eventually higher levels of welfare, is it ever optimal for this country to borrow from abroad to expand domestic investment?

- Will a country following an optimal saving plan run through stages in its balance of payments in which it first acquires debt, then begins to reduce its liabilities to foreigners and then reach a point where it is actually a net creditor to the rest of the world?

In practically all of the simpler models that exist in the literature, the answer to all of these questions is "no". However, when the economy produces investment goods and non-traded goods, the answer to all three questions may be "yes".

The first question is the one raised by Feldstein and Horioka (1980) and subsequently studied by, for example, Feldstein (1983), Obstfeld (1986), Frankel (1985) and Summers (1986). Feldstein and Horioka in essence argue 
that if financial capital is perfectly mobile that all countries face the same real interest rate. The desired capital stock (and, thus, the level of investment) is assumed to depend only on the real interest rate. Hence, investment decisions are made independently of any saving choices. We show that in the presence of non-traded goods, saving choices affect the marginal productivity of capital. In this environment, saving and investment decisions within a country are closely linked, even though there is free asset trade and the real interest rate is determined on international capital markets.

As we will show, the second question is closely related to the first. We demonstrate that if the rate of time preference for planners falls, it may be optimal to borrow from abroad. This seeming paradox contradicts the usual presumption, as discussed for example in Buiter (1981) and Frenkel and Razin (1986), that more impatient countries borrow from abroad. Critical to explaining our result (which in turn may help to explain the Sachs (1981) observation that many developing countries seemed to be borrowing to finance domestic investment) is the presence of an investment good and a non-traded good.

The stages in the balance of payments theory has a long history, and has from time to time in recent years provoked interest. (See Eaton (1986) for a survey of the field.) Probably the most prominent recent paper to study the phenomenon is Fischer and Frenkel (1972). Although seemingly plausible behavior could lead to the familiar stages, Bazdarich (1978) built a model in which saving behavior is optimal and demonstrates in that context that stages are impossible. The consumption dynamics that are allowed in his model are, however, limited, and we show that under slightly richer assumptions the stages theory can be rehabilitated.

The general plan of this paper is to discuss why simple models give misleading answers to the three questions posed. We show why the presence 
of investment goods and non-traded goods is important. Although we examine these questions informally in general terms, we do not proceed by proving general theorems that hold for economies with $n$ goods and $m$ factors of production (and $x$ non-traded goods and $y$ immobile factors, and so on). Instead our formal model is a simple and familiar two sector model. The generalization to many goods and factors, when possible, would follow as in higher order trade theory (see the surveys by Ruffin (1984) and Ethier (1984)).

Section 2 of this paper first lays out the two sector model. The second part of this section contains the general discussion of the three questions posed above. In section 3, the model is solved. The final section contains concluding remarks.

2. Non-Traded Goods and Investment Goods

\section{A. The Model}

The economy of our simple model produces two goods: a non-traded consumption good and a traded good which is a composite good that can be used either for production or consumption. ${ }^{1}$ A planner, or given the absence of externalities, a representative consumer maximizes utility over an infinite horizon. There is a freely traded bond. The country is small in the market for traded goods and in international bond markets.

The two goods are produced with a constant returns to scale technology. There are two factors of production, capital and labor, that are freely mobile between industries.

There are perhaps two assumptions we make that are controversial. The 
implication of the above assumptions that physical capital is freely traded and freely mobile between industries is that there are no lags in investment. When the desired capital stock changes, all the desired new investment or disinvestment can occur instantaneously. Perhaps it would be more desirable to make some assumptions that caused the capital stock to adjust slowly. For example, investment could be assumed to be irreversible; there could be a cost to new investment; and, there could be a cost to importing physical capital. We do not make these assumptions because, even though they would make the model more realistic, they would complicate the model considerably and have the unfortunate consequence of obfuscating the key economic behavior we want to focus on. Thus, we will look at changes in the desired capital stock. In our model these desired changes will translate into actual changes with no delay, but the reader may wish to think of them in real life as changes in a target capital stock which will be approached over time through investment.

The second controversial assumption involves our modelling of the rate of time preference. It is well known that difficulties arise under the assumption of a constant rate of time preference if the consumers have an infinite horizon and face a given interest rate. Either no steady state can be approached, or consumption expenditures are constant. At least two ways exist in the literature to avoid this problem: either assume a finite horizon, or let the consumer's discount rate vary endogenously. We choose the second approach, and parameterize the rate of time preference as does Uzawa (1968). The assumption of Uzawa that provokes disagreement is that the discount rate is an increasing function of the level of current utility. There is little empirical evidence to support (or refute) this assumption. ${ }^{2}$ In this paper, however, none of our major insights depend on this property. We are interested in how the economy changes when desired saving increases. We generate an increase in saving by allowing a shift down in the rate of 
time preference. Under almost any conditions, lower time preference should mean higher desired saving - there is nothing special about this.

Output of each good can be expressed by the functions:

$$
\begin{gathered}
y_{T}=v f\left(k_{T}\right) \\
y_{N}=(1-v) g\left(k_{N}\right),
\end{gathered}
$$

where $v$ is the amount of labor used in the traded goods sector, $k$ refers to the capital-labor ratio in each sector, and the subscripts $T$ and $N$ refer to the traded and non-traded sectors repectively. (The total labor supply does not grow and is fixed at 1.)

The traded goods price is given and equal to 1 , and the price of the non-traded good is $p$. Under constant returns to scale, cost functions depend only on the factor prices - $w$, the wage; and $r$, the internationally given interest rate. Equating prices to costs

$$
\begin{gathered}
1=C_{T}(w, r), \text { and } \\
p=C_{N}(w, r) .
\end{gathered}
$$

From these equations it follows that the wage and the price of non-traded goods are completely determined by the interest rate, and are therefore fixed over time. Furthermore, the capital-labor ratios in each industry are constant, because goods and factor prices are constant and marginal productivities depend only on the $k^{\prime} s$.

Utility is homothetic, which means that consumption of each good, $c$, is proportional to total consumption expenditure, $z$ (since $p$ is constant):

$$
\begin{gathered}
c_{T}=\alpha z \text {, and } \\
c_{N}=(1-\alpha) z / p
\end{gathered}
$$

Letting $\mathbf{k}$ denote the total capital stock, it follows that

$$
z=\eta+\beta k
$$


where

$$
\begin{aligned}
& \eta=\mathrm{p}\left[\mathrm{k}_{\mathrm{T}} \mathrm{g}\left(\mathrm{k}_{\mathrm{N}}\right)\right] /(1-\alpha)\left(\mathrm{k}_{\mathrm{T}}-\mathrm{k}_{\mathrm{N}}\right) \text {, and } \\
& \beta=-\eta / k_{\mathrm{T}} .
\end{aligned}
$$

We see that consumption expenditures are a linear function of the capital stock. If the traded goods industry is capital intensive, then $\beta$ is negative. In this case as expenditures fall, the desired (and actual) capital stock must rise. A decrease in expenditure implies a decrease in spending on the non-traded good. Production of the non-traded good must fall. Factors are released to the traded goods sector. However, the non-traded goods sector releases proportionally too much labor. This would lead to potentially a higher marginal productivity of capital in the traded goods sector. The desired capital stock rises.

The reverse relation between expenditure and the capital stock would hold if non-traded goods were capital intensive.

Each consumer maximizes

$$
v=\int_{0}^{\infty} v\left(z_{t}\right) e^{-\Delta(t)} d t
$$

In this expression, $v$ represents the indirect instantaneous utility function. The rate of time preference is not constant, but instead varies over time as the level of expenditure changes:

$$
\Delta(t)=\int_{0}^{t} \delta\left(v\left(z_{s}\right)\right) d s .
$$

Following Uzawa, we assume $\delta, \delta^{\prime}, \delta^{\prime \prime}$, and $\delta \cdot \delta^{\prime} \mathrm{v}$ are all positive. ${ }^{3}$ The assumption which guarantees that the economy will converge toward a steady-state is $\delta^{\prime}>0$. It essentially requires that as income, $v$, increases, the rate of time preference rise so that saving will fall. If the opposite assumption were made, the rich would get richer and the poor would get poorer and the economy would be unstable.

Each consumer faces the dynamic budget constraint 


$$
\dot{\mathrm{w}}=\mathrm{rW}+\mathrm{w}-\mathrm{z} \text {. }
$$

Here, W represents total tangible wealth, which is the sum of $k$, the capital stock, and b, net claims on the rest of the world. Both forms of wealth earn the same rate of return. As explained above, should the net marginal productivity of capital (the gross MPK less the depreciation rate $n$ ) exceed the world interest rate, capital goods are immediately imported to the point where the equality is restored.

We also need to impose independently the condition that

$$
\lim _{t \rightarrow \infty} b_{t} e^{-r t} \geq 0
$$

Without such a constraint, with the infinite planning horizon any level of utility could be achieved by borrowing an arbitrary amount at some time and meeting interest payments through further borrowing.

With this model in mind, we now return to the questions of the previous section.

B. General Discussion

1. Suppose for a small country that all goods are traded, and there are more factors of production than there are goods. Suppose further that investment can occur, but the total supply of all other factors of production is fixed over time. Let financial capital be mobile, so that the real interest rate is determined exogenously for this small economy. Then the desired total capital stock in this country - - indeed, the capital stock in each industry -- is fully determined. Investment decisions in no way depend on consumption or saving decisions.

This seems to be the economic background that Feldstein and Horioka have in mind when they state that in a world of perfect financial capital 
mobility, saving and investment decisions will be uncorrelated across countries. (Note as Obstfeld (1986) points out, or as can be seen immediately from Persson and Svensson (1985), even in this world, saving and investment can be correlated if they react to shocks in the same direction.) However, in the presence of non-traded goods, this independence of saving and investment breaks down. Production decisions obviously depend on consumption choices for the non-traded goods. As saving rises, suppose consumption of non-tradeables falls. For market equilibrium, production of home goods must fall. However, the factor mix in the non-traded sector need not be the same as in the traded sector. As production in the home goods sector shrinks, factors of production must migrate to find employment. If the non-traded sector is relatively labor-using, then marginal productivity of capital will rise in the economy when home goods production shrinks. This in turn implies the desired capital stock will rise, and there will be a positive relation between saving and investment. 4

The model described in section 2.A above is a particularly simple example of this. The two factor, two good set-up ensures a constant price of the non-traded good. This makes things easy, since all the decreased demand for home goods is translated into a drop in production of those goods (rather than having the decreased demand being shared between a fall in the relative price of non-tradeables and a drop in their output). Also, the constant price in conjunction with the homotheticity assumption ensures that the fall in home goods demand is simply proportional to the fall in total expenditures. The fact that investment goods are traded and capital is mobile between sectors also simplifies things (as discussed above) because it allows adjustment to the desired capital stock to occur immediately.

An intuitive real world explanation would say that low saving, high consumption countries would have to satisfy some of their desired consumption through imports. Therefore, the production structure in these 
countries will be biased toward non-traded goods. (We are assuming here that there is no particular relation between the level of saving and the desired consumption mix between traded and home goods.) To the extent that home goods tend to be such labor intensive goods as non-traded services, then investment levels in these countries will be lower. So, countries in which saving levels are low will also tend to have low levels of investment. 2. When will a country that decides to postpone consumption also choose to borrow from abroad? It is unlikely that such behavior could arise in a model without investment. Suppose consumption of all goods declines. If all goods are traded, there must immediately be a current account surplus. If there are both home goods and traded goods, production of non-traded goods must fall, which, for a given production possibility frontier, means production of tradeables must rise. If production of traded goods goes up, and consumption of those goods goes down, the country must run a current account surplus and lend abroad.

Even allowing for investment, it will still be the case that higher saving will lead necessarily to a current account surplus if all goods are traded. This follows from the discussion above on the Feldstein and Horioka point. In such an environment, investment decisions are independent of saving decisions. Suppose the country wishes to save now to increase its long run income. It would be better off lending abroad rather than investing at home. Adding to the capital stock at home would reduce the marginal productivity of capital below the world interest rate. They could always earn more on foreign bonds.

In such a context it is hard to establish a relation between high saving and a higher target capital stock. Of course high saving countries may turn out to be borrowing to finance investment just because they happen to be capital scarce. A country, for example, that simultaneously removes restrictions on financial capital flows and increases saving might find 
itself in this position. But the Feldstein-Horioka problem remains for countries that have maintained fairly free asset trade.

In the presence of non-traded goods this reasoning no longer applies. As argued above, if home goods are relatively labor intensive, then reduced consumption of these goods increases the marginal productivity of capital at home and induces domestic investment. It may make sense to borrow from abroad to finance this increased investment.

In the model laid out above, if the home goods sector is labor intensive, the country will initially borrow from abroad if its rate of time preference shifts down. This follows because in this case the desired capital stock at home becomes higher. Since in this model capital goods are freely traded, the country will initially borrow enough from the rest of the world to pay for imports of capital goods to bring the capital stock up to its optimal level.

3. The literature on stages in the balance of payments says that a country will go through five stages in its transition to steady state: a) a young debtor borrower - - its trade balance and current account are both in deficit, and it is a net debtor to the rest of the world; b) a mature debtor borrower - - its trade balance is in surplus but the current account is still in deficit because of its debt-service obligations; c) a debtor-repayer - the country is still a net debtor, but its current account is now in surplus; d) a young creditor-lender -. the country becomes a net creditor, and its trade account and current account are in surplus; and, e) a mature creditor-lender -- the creditor country runs a trade deficit, but its current account remains in surplus as it earns interest income from the rest of the world. In steady state the country is a net creditor, whose trade deficit is exactly offset by its earnings on foreign assets.

It is unlikely that a country would pass through such stages just because of variations in its consumption behavior. The country passes 
through stages of trade balance deficit, then surplus, then deficit again. Consumption would have to adjust non-monotonically to steady state to generate such a pattern of trade account imbalances. It seems very likely that the mechanism that would lead a country through such stages is an interaction of saving and investment decisions.

A less developed country may initially be capital scarce. In the early stages of its development it might be borrowing to build up its capital stock until the marginal productivity of capital is equated with the world interest rate. As the capital stock approaches its target level, the investment motive for borrowing may wane. At that stage the country may still have high saving rates (as it is still trying to grow to its optimal income level), so it may start running a trade surplus and eventually a current account surplus. Eventually it would turn into a creditor and in steady state would support a high level of consumption with earnings from foreign loans.

In our model it is very possible for a country to go through exactly these stages. Actually, the first stage in which the country adjusts its capital stock happens instantaneously in the model because of the absence of any costs of changing the capital stock. The model of Bazdarich (1978) is an optimizing model which precludes stages. For the case in his model in which a steady state is approached (when the constant rate of time preference equals the world interest rate), consumption is constant over time. That model is one for which there are investment dynamics, but no consumption dynamics.

In the next section we formally examine the model laid out in part 2.A. 
3. The Solution of the Model

In this section we will first derive the first-order conditions for the optimization problem. Then we will examine the steady-state. Next we will characterize the dynamics near the steady-state to demonstrate the system is saddle-stable. Finally, we will discuss the evolution of the the capital stock and foreign assets as shown in phase diagrams. We will restrict attention to regions where the economy remains incompletely specialized in the production of both goods. 5

Following Uzawa (1968) and Obstfeld (1981), it is useful to rewrite eq.

(2) as

$$
V=\int_{0}^{\infty}[v(z) / \delta(v(z))] e^{-\Delta} d \Delta
$$

The Hamiltonian for the optimization problem can then be written as

$$
H=(1 / \delta(v(z)))[v(z)+q(r W+w-z)]
$$

The first-order conditions become

$$
\begin{gathered}
\mathrm{q}=\left[\mathrm{v}^{\prime}\left(\delta-\delta^{\prime} \mathrm{v}\right)\right] /\left[\delta+\delta^{\prime} \mathrm{v}^{\prime} \dot{\mathrm{w}}\right] \text {, and } \\
\dot{\mathrm{q}}=(\delta-\mathrm{r}) \mathrm{q} .
\end{gathered}
$$

In the steady state, setting $\dot{q}=0$ in eq. (5), the rate of time preference must adjust into equality with the given interest rate: $\delta(v(z))=$ $r$. Thus the steady state level of expenditure is determined independently from the rest of the system. There is effectively a target level of expenditure. Suppose we consider the effect of a drop in the rate of time preference - a shift down in the $\delta$ function. This could be interpreted as a change in preferences on the part of consumers or the planner toward 
giving more weight to the future. Indeed, in the steady state, expenditures would rise.

With an increase in long-run spending, the steady-state capital stock will rise or fall as $\beta$ in eq. (1) is positive or negative. That is, if the home goods industry is capital intensive the capital stock will rise, and if the home goods industry is labor intensive the capital stock will fall. This is just the Rybczynski theorem in reverse - to induce expansion of the labor-intensive industry the capital stock must fall, and to induce expansion of the capital-intensive industry the capital stock must rise.

It can also be demonstrated that the steady-state trade deficit must increase when long-run expenditures rise, which in turn implies that claims on foreigners must be higher to generate enough income to support this deficit. The trade deficit is equal to net national product less the level of expenditure. The increase in expenditure contributes to a higher trade deficit. The change in net national product in the long run is of course just the interest rate times the change in the capital stock. If the capital stock falls (i.e., if home goods are labor intensive) then clearly there must be a greater long-run trade deficit. Even in the case in which the capital stock expands (when home goods are capital intensive), the increase in net national product must be less than the increase in expenditure. This follows because gross output must increase more than net output (the difference being depreciation). The output of non-traded goods must go up more than total gross output, since the output of the traded goods sector would actually shrink (again the Rybczynski theorem -. an increase in the capital stock causes the labor-intensive industry to contract). But output of non-traded goods, which equals consumption of non-traded goods, goes up less than total expenditure. Hence the long-run trade deficit must rise, and holdings of foreign bonds, b, must expand in the steady state. 
To examine the dynamics of the system, logarithmically differentiate eq. (4) and equate it to eq. (5) to obtain:

$$
\begin{gathered}
\delta-\mathrm{r}=\mathrm{D} \dot{\mathrm{z}}-\left[\left(\delta^{\prime \prime} \mathrm{v}^{\prime 2}+\delta^{\prime} \mathrm{v}^{\prime \prime}\right) \dot{\mathrm{W}} \dot{\mathrm{z}}-\delta^{\prime} \mathrm{v}^{\prime} \mathrm{r} \dot{\mathrm{W}}\right] /\left[\delta^{\prime} \mathrm{v}^{\prime} \dot{\mathrm{W}}+\delta\right] \text {, where } \\
\mathrm{D} \equiv\left[\mathrm{u}^{\prime \prime}\left(\delta-\delta^{\prime} \mathrm{u}\right)-\delta^{\prime \prime} u u^{\prime}{ }^{2}\right] / \mathrm{u}^{\prime}\left(\delta-\delta^{\prime} \mathrm{u}\right)<0 .
\end{gathered}
$$

Equations (3) and (6) comprise a two equation dynamic system in $z$ and $w$ that characterize the path of the economy. The behavior of the capital stock can be derived from knowing $z$, since $k$ is just linearly related to $z$. Total claims on foreigners is given by the difference between $W$ and $k$.

To examine the stability of the system, we linearize eqs. (3) and (6) near steady-state to obtain:

$$
\left[\begin{array}{c}
\dot{z} \\
\dot{W}
\end{array}\right]=\left[\begin{array}{cc}
0 & \delta \delta^{\prime} \mathrm{u} / \mathrm{D} \\
-1 & \mathrm{r}
\end{array}\right]\left[\begin{array}{c}
\mathrm{z}-\overline{\mathrm{z}} \\
\mathrm{W}-\overline{\mathrm{W}}
\end{array}\right] \text {. }
$$

(The "-" above a variable represents its long-run value. There is a unique steady-state.) The determinant of the system equals $\delta \delta^{\prime} u / D$, which is negative. The system must have one negative and one positive root, which implies it is saddle stable. The transversality conditon gives a sufficient condition for optimality. In this case it may be written:

$$
\lim _{\Delta \rightarrow \infty} e^{-\Delta} \mathrm{qW}_{\Delta}=0
$$

Along the path that leads to the steady state, this condition is satisfied, so it is an optimal path. Notice also that if the transversality condition is met that the intertemporal budget constraint is also obeyed.

It is useful to draw the phase plane in $b, k$ space as in Figure 1 because those are the variables we are most interested in. Near the steady-state the $\dot{z}=0$ line is not a function of $z$, so in $b, k$ space it has a slope of -1 . Away from the steady-state we do not know much about this 1 ine, except that it crosses the $\dot{W}=0$ line only at the steady-state. 
In Figure la the $\dot{W}=0$ line slopes upward, which is the case when home goods are capital intensive. In discussing the steady state above we showed why an increase in the capital stock must be associated with an increase in $b$ in this case. Note that the $\dot{W}=0$ line is linear everywhere, not just near the steady-state.

In Figure lb the $\dot{W}=0$ line slopes downward, which is the case when home goods are labor intensive. Notice that the $\dot{W}=0$ line cuts the $\dot{z}=0$ line from above, indicating that at the steady state the $\dot{W}=0$ line has a slope less than -1. Suppose long-run bond holdings go up one unit. If the long run capital stock fell by exactly one unit then $\dot{W}$ would no longer equal zero. Total wealth would be unaffected by such a switch but expenditures would have to rise, since in this case there is a negative relation between the capital stock and total expenditure. Therefore a one unit increase in bond holdings must be accompanied by a less than one unit drop in $k$ to keep wealth accumulation constant.

The arrows in Figure 1 denote the direction of motion. The dotted line in each case denotes the saddle path. This diagram is drawn assuming incomplete specialization in production of both goods.

Figure 2 demonstrates the dynamic path of the economy in response to a drop in $\delta$-. i.e., an increased concern for the future. The economy is initially in steady-state at point a. The change in the rate of time preference has no effect on the $\dot{\mathrm{w}}=0$ line, but as we have already discussed, it leads to an increase in long-run claims on foreigners.

Figure $2 \mathrm{a}$ shows the case in which home goods are capital intensive. In the long-run both the capital stock and foreign bond holdings are higher. Initially in response to the drop in the $\delta$ function the economy must jump from a to $a^{\prime}$ to get on the new saddle path. It initially sells some of its capital stock and uses the proceeds to lend abroad. It continues to run a current account surplus, but also accumulates physical capital as it 


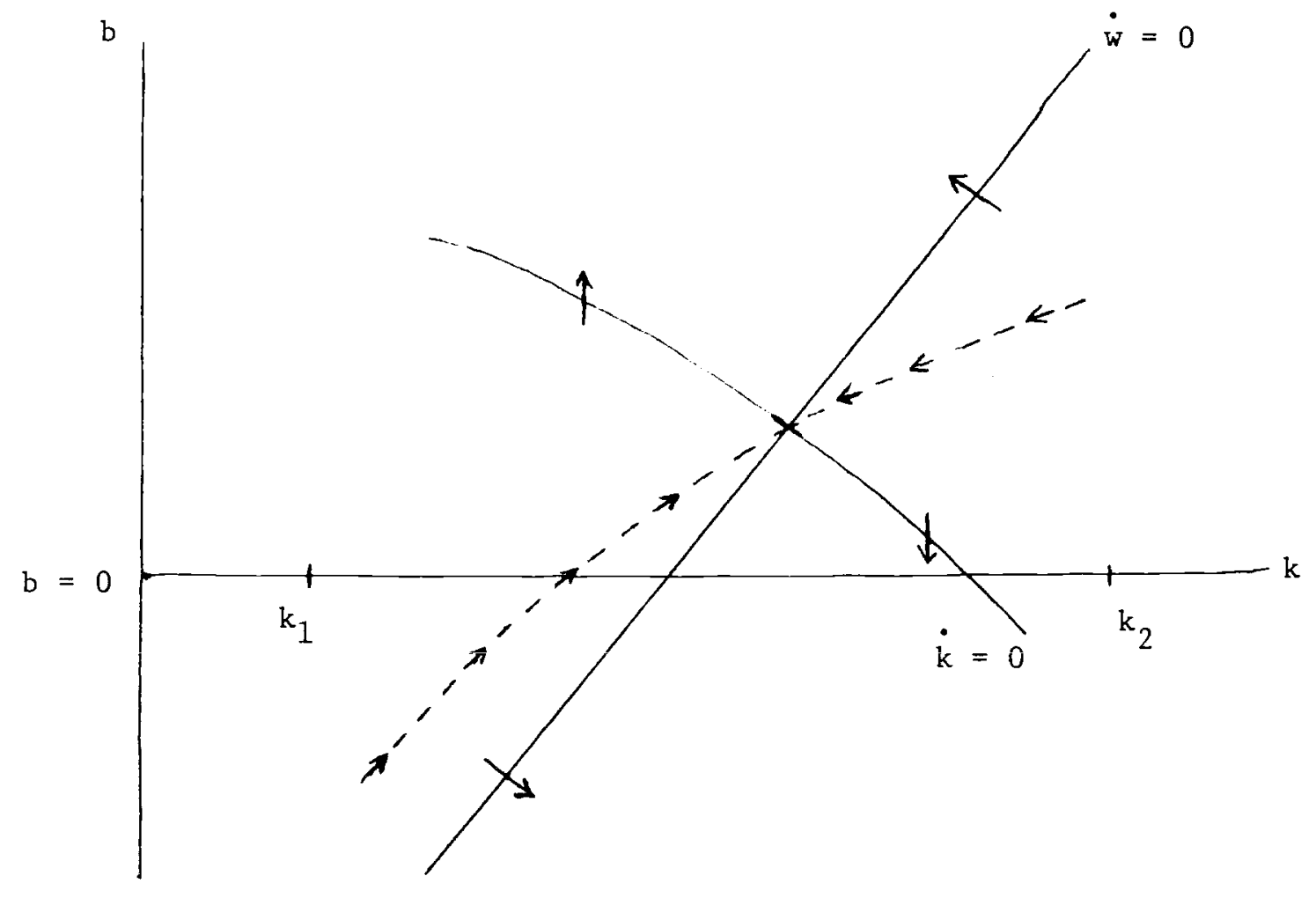

(a) $\mathrm{k}_{2}>\mathrm{k}_{1}$

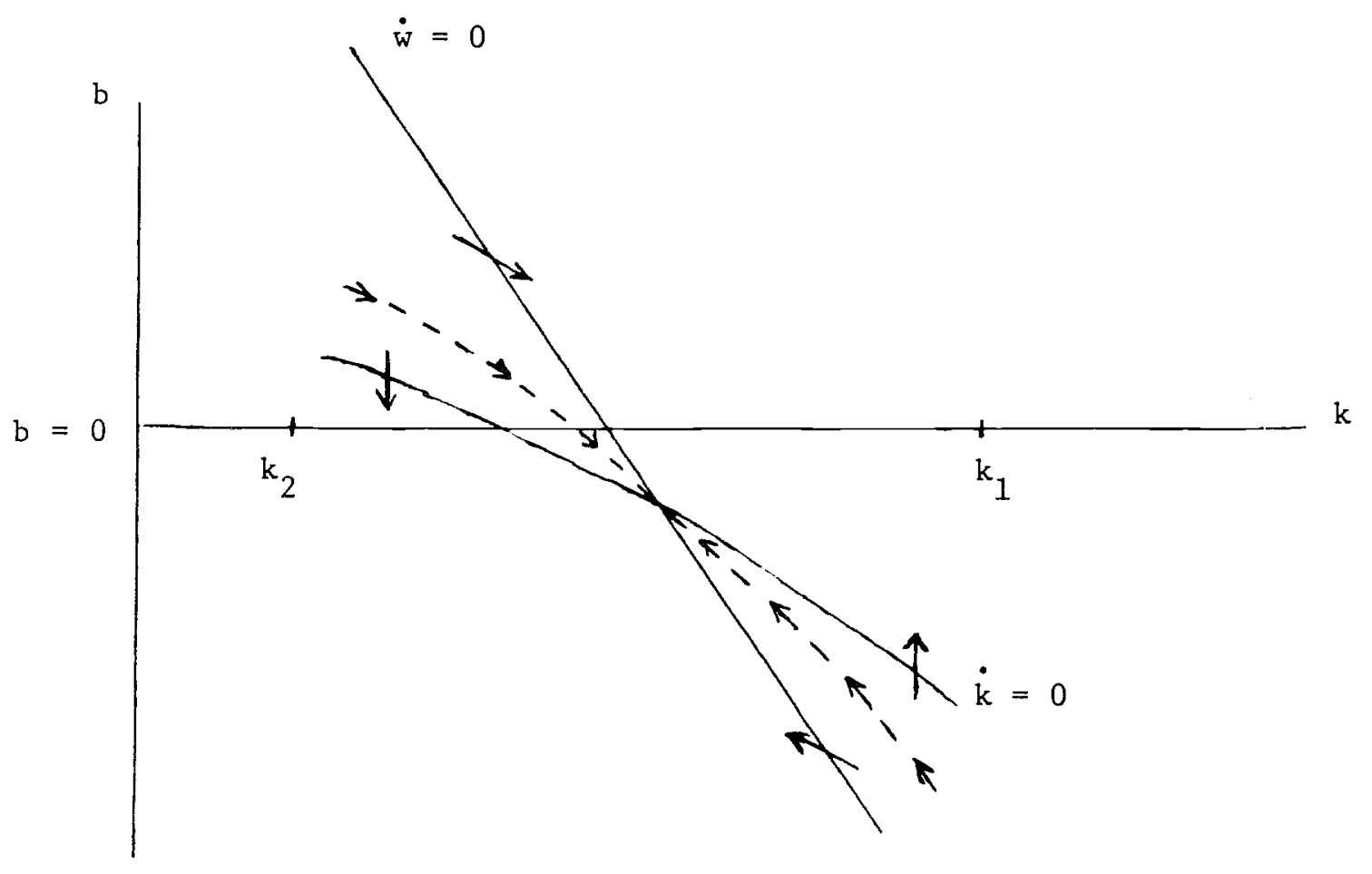

(b) $\mathrm{k}_{1}>\mathrm{k}_{2}$

Figure 1 

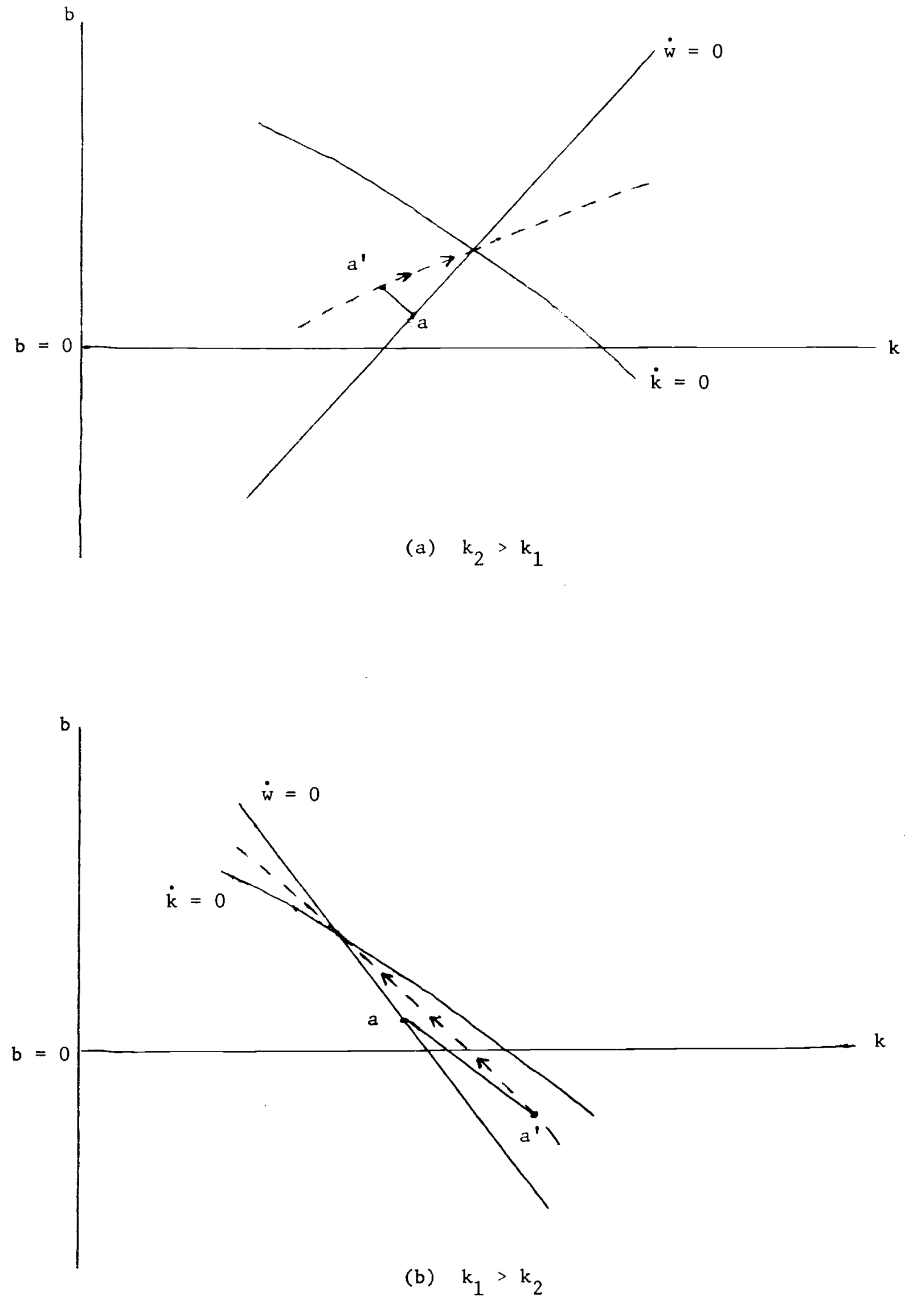

Figure 2 
approaches the steady state.

Figure $2 \mathrm{~b}$ shows the case which is more relevant for questions 1 and 2 posed in the introduction. Here, the long-run capital stock falls when the rate of time preference falls. Initially, however, as the economy moves to the new saddle path (from a to $a^{\prime}$ ), the capital stock is increased. This new investment is financed with borrowing from abroad. Then along the path to the new steady state, the capital stock declines while the country runs a current account surplus.

In this case, the initial increase in desired saving is accompanied by an increase in the desired stock of capital. Because of the free mobility of physical capital, all the investment occurs instantaneously. In this initial stage, the discrete increase in the capital stock must be financed through foreign borrowing.

Figure 3 depicts a sequence of events that is consistent with stages in the balance of payments. The country is initially at a point such as $x$, where it is capital poor. It immediately runs a current account deficit and acquires capital as it moves from $x$ to $y$. This corresponds to the debtor-borrower stage. As the country moves from $y$ to $z$, it reduces its debt to the rest of the world. It passes through is debtor repayer stage. From $z$ to the steady state the country is a creditor. Initially it is a young creditor lender as its trade account is in surplus. As steady state is approached, the trade account falls into deficit. In the long run the current account is balanced, with interest receipts on foreign loans just offsetting a trade deficit. 


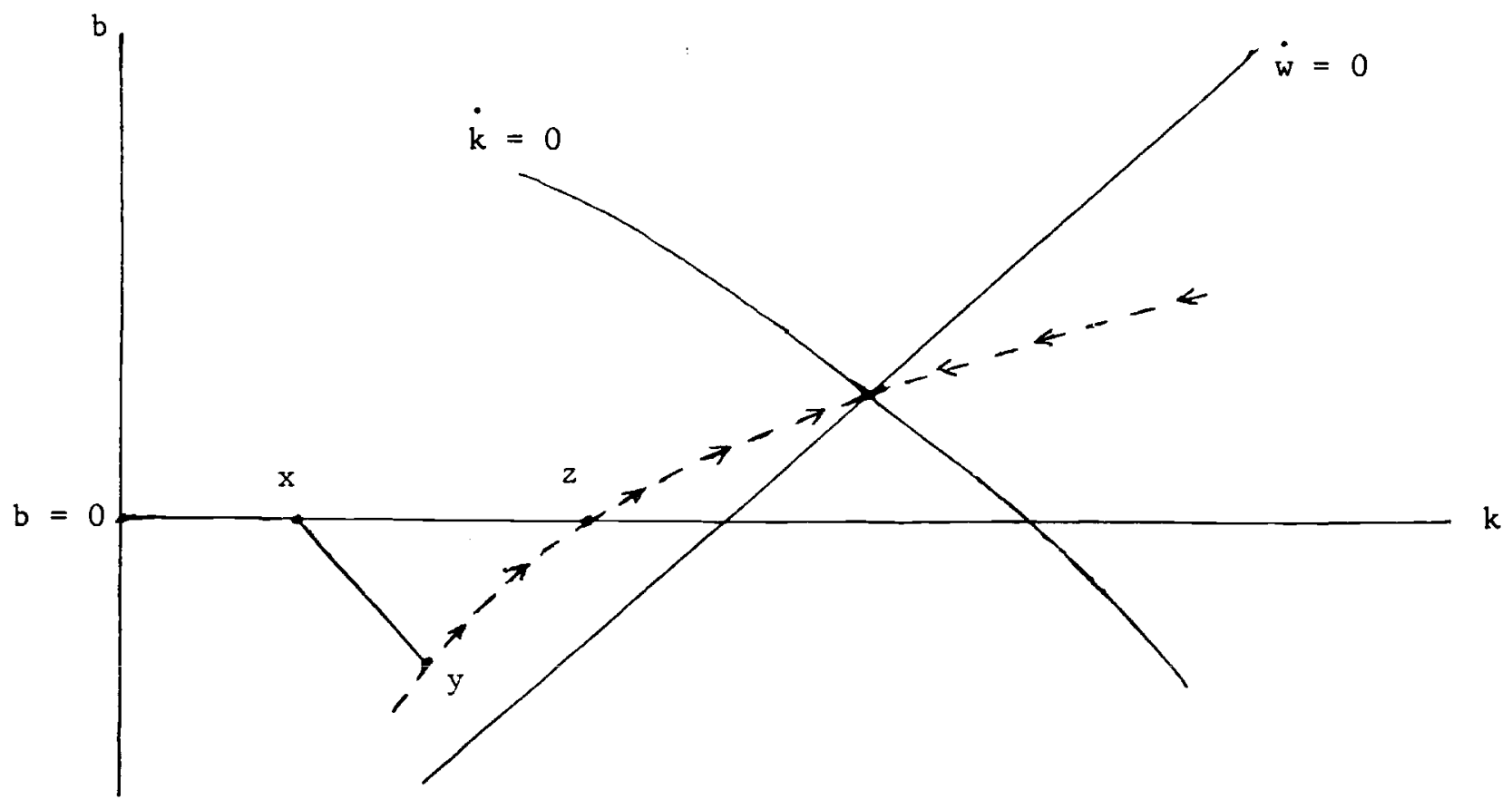

(a) $k_{2}>k_{1}$

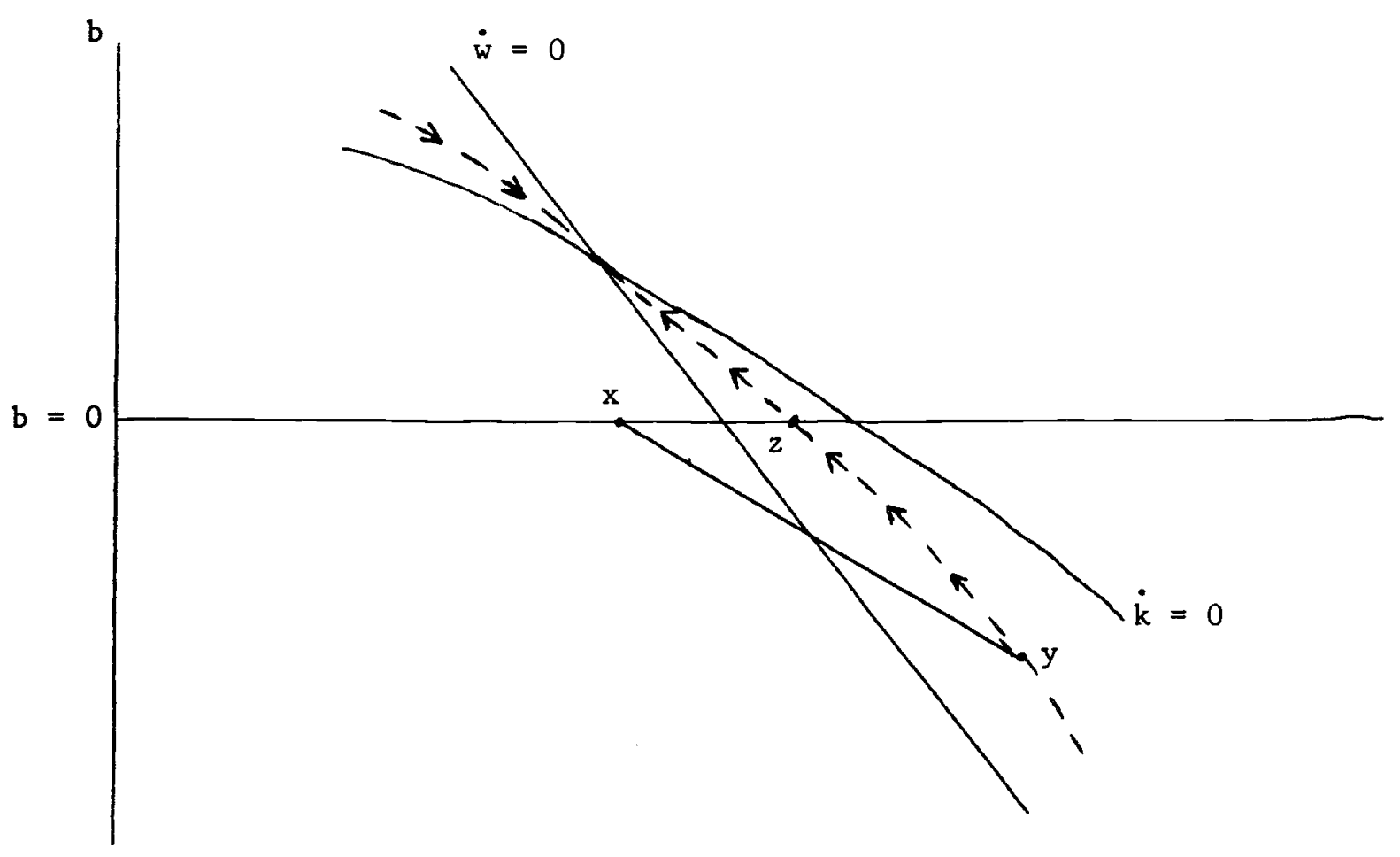

k

(b) $\mathrm{k}_{1}>\mathrm{k}_{2}$

Figure 3 
4. Conclusion

This paper builds a simple framework that allows us to examine some questions concerning saving and investment in countries that have free access to international financial markets. We discussed in general terms conditions which might lead to a dependence of the level of investment on the level of saving. Indeed, we found that an increase in saving might even lead to greater borrowing from abroad. We also found that passing through stages in the balances of payments can be consistent with optimizing behavior. 


\section{Footnotes}

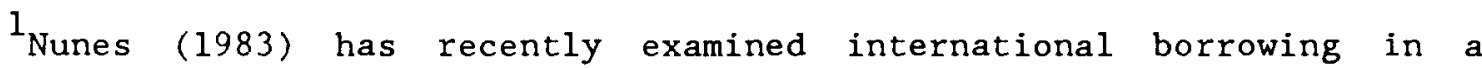
similar framework. However, his assumption of a constant rate of time preference equal to the world interest rate precludes any of the dynamics of interest discussed in this paper.

2 There is some evidence to support the Uzawa specification. One of its implications is that there is a stable stationary equilibrium consumption level. (This is indeed the implication that causes the most controversy.) Clower and Johnson (1968), however, find that such a specification has empirical support. An experimental study (as yet unpublished) by Raymond Battalio of Texas $A \& M$ University shows that low income (underfed) rats tend to have a lower discount rate than high income (well fed) rats. This is exactly consistent with Uzawa's assumptions.

${ }^{3}$ Obstfeld (1981) discusses these assumptions. The assumption that $\delta$ $-\delta^{\prime} v$ is positive ensures that $\mathrm{V}$ in steady-state $(-\mathrm{v} / \delta)$ is increasing in $\mathrm{v}$.

${ }^{4}$ Implicit in Frankel (1985) is the notion that non-traded goods might cause the Feldstein - Horioka claim to break down. He might argue that there is no force to determine the own real rate of interest for non-traded goods, because while free financial capital markets can equalize nominal interest rates, they cannot equalize rates of inflation of goods prices. Note however that this argument must be logically separate from the one presented here. In our simple model, the price of home goods relative to traded goods remains fixed, so the real interest rate relative to home goods is the same as $r$. Nonetheless, there is a relation between saving and investment. 
5 The dynamics for the general case of this model, including non-traded goods, are examined in Engel and Kletzer (1986). 


\section{References}

Bazdarich, M., "Optimal Growth and Stages in the Balance of Payments," Journal of International Economics 8 (August 1978): 425-443.

Buiter, W., "Time Preference and International Lending and Borrowing in an Overlapping-Generations Mode1," Journal of Political Economy 89 (August 1981): $769-797$.

Clower, R. and M. Johnson, "Income, Wealth and the Theory of Consumption," in J.N. Wolfe, ed., Value, Capital and Growth: Papers in Honor of Sir John Hicks (Chicago: Aldine, 1968).

Eaton J., "Foreign Public Capital and Economic Development," in H. Chenery and T.N. Srinivasan, eds., Handbook of Development Economics (Amsterdam: North-Holland, forthcoming).

Engel, C. and K. Kletzer "International Borrowing to Finance Investment," National Bureau of Economic Research Working Paper \# 1865 (March 1986). Ethier, W. "Higher Dimensional Issues in Trade Theory," in R. Jones and P. Kenen, eds., Handbook of International Economics (Amsterdam:

North-Holland, 1984).

Feldstein, M., "Domestic Saving and International Capital Movements in the Long run and the Short run," European Economic Review 21, (March 1983): $129-151$.

Feldstein, M. and C. Horioka, "Domestic Saving and International Capital Flows," Economic Journal 90: (June 1980), 314-329.

Fischer, S. and J. Frenke1, "Investment, the Two-Sector Mode1, and Trade in Debt and Capital Goods," Journal of International Economics 2 (August 1972): 211-233. 
Franke1, J. "International Capital Mobility and Crowding out in the U.S. Economy: Imperfect Integration of Financial Markets or of Goods Markets?" National Bureau of Economic Research Working Paper \# 1773 (December 1985).

Frenkel, J. and A. Razin, "Fiscal Policies in the World Economy," Journal of Political Economy 94 (June 1986): 564-594.

Nunes, L. "Optimal Capital Accumulation and External Indebtedness in a Two Sector Small Economy Model," University of Chicago, October 1983.

Obstfeld, M. "Macroeconomic Policy, Exchange-Rate Dynamics, and Optimal Asset Accumulation," Journal of Political Economy 89 (December 1981): $1142-1161$.

Obstfeld, M. "Capital Mobility in the World Economy: Theory and Measurement," Carnegie - Rochester Conference Series on Public Policy 24 (Spring 1986): 55-104.

Persson, T. and L. Svensson "Current Account Dynamics and the Terms of Trade: Harberger-Laursen-Metzler Two Generations Later," Journal of Political Economy 93 (February 1985): 43-65.

Ruffin, R. "International Factor Movements," in R. Jones and P. Kenen, eds., Handbook of International Economics (Amsterdam: North-Holland, 1984). Sachs, J. "The Current Account and Macroeconomic Adjustment in the 1970s," Brookings Papers on Economic Activity 12 (1981): $201-282$.

Summers, L. "Tax Policy and International Competitiveness," National Bureau of Economic Research Working Paper \# 2007 (August 1986).

Uzawa, H. "Time Preference, the Consumption Function, and Optimum Asset Holdings," in J.N. Wolfe, ed., Value, Capital and Growth: Papers in Honor of Sir John Hicks (Chicago: Aldine, 1968). 